\title{
Weed Interference and Control in Cowpea Production: A Review
}

\author{
O. Adewale Osipitan ${ }^{1}$ \\ ${ }^{1}$ Northeast Research and Extension Center, University of Nebraska-Lincoln, USA \\ Correspondence: O. Adewale Osipitan, Northeast Research and Extension Center, University of \\ Nebraska-Lincoln, 57905866 Road, Concord, NE 68728-2828, USA. E-mail: waleos08@yahoo.com \\ Received: September 18, 2017 \\ Accepted: October 14, $2017 \quad$ Online Published: November 15, 2017 \\ doi:10.5539/jas.v9n12p11 \\ URL: https://doi.org/10.5539/jas.v9n12p11
}

\begin{abstract}
In spite of the great economic potential of cowpea as both domestic and commercial crop, a number of constraints, which include insect pests, diseases and weeds, limits its production in West and many parts of Africa. Weeds reduced cowpea yield and value by competing for light, water and nutrients. Cowpea suffers from weeds particularly when the crop is in the early growth stages before ground cover. Yield losses cause by weeds alone in cowpea production can be as high as $76 \%$ depending on the cowpea cultivar, environment and weed management practices. A timely weed removal at the critical period, which falls within the first 40 days of cowpea growth, would help to prevent an unacceptable yield. Weed management in cowpea has been with low technology. Hand weeding is the most widely used weed control method in cowpea but they are usually expensive and labour intensive. Cultural practices such as narrow row spacing and planting of early maturing varieties are also used for weed control in cowpea. Herbicides, which are relatively easy to use and less expensive, have not been widely adopted for weed control in cowpea. There are limited number of selective herbicides with wide spectrum for weed control in cowpea. However, an integrated practices that involved pre-emergence weed control using herbicides or physical weeding, and a supplementary weed removal that would ensure weed control up to 40 days after cowpea emergence could substantially prevent yield losses associated with weed interference.
\end{abstract}

Keywords: cowpea, weed interference, weed control

\section{Introduction}

Cowpea (Vigna unguiculata (L.) Walp) is one of the most important grain legume in many countries of the tropics particularly Asia and Africa. Cowpea is cultivated for food, feed and as a cash crop (Langyintuo et al., 2003; Asiwe \& Kutu, 2007). It was estimated that cowpea supplies about $40 \%$ of the daily protein requirements to most of the people in West Africa. Cowpea has a high potential to increase farmers' and traders' incomes, thereby contributing to poverty reduction and food security (Kormawa et al., 2000).

The world estimated annual cowpea production is put at 4.5 million tonnes from an estimated land area of 12.6 million hectares (Food and Agriculture Organization [FAO], 2014). West Africa accounts for about $80 \%$ of the estimated total land area under cowpea cultivation. Nigeria is the largest producer and consumer of cowpea with about 5 million hectares area and 2.4 million tonnes production annually.

In spite of the great economic potential of cowpea as both domestic and commercial crop, a number of constraints limits its production in West and many parts of Africa. These constraints include insect pests and diseases (Thio et al., 2016; Abudulai et al., 2017), inadequate knowledge of good cultural practices and high yielding varieties resulting in poor yield (Ajeigbe et al., 2005). Other constraints include planting at sub-optimal plant density, low soil fertility and drought and weeds (Adigun et al., 2014; Kanteh et al., 2014; Adusei et al., 2016; Osipitan et al., 2016).

\section{Weed Problem in Cowpea}

Weeds constitute a major constraint to crop production globally. Yield losses cause by weeds alone in cowpea production can range from $25 \%$ to $76 \%$ depending on the cultivar and environment (Adigun et al., 2014; Gupta et al., 2016; Osipitan et al., 2016; Ugbe et al., 2016). Problems caused by weed in cowpea production include reduction in crop yield, less efficient land use, higher cost of production due to insects and plant disease control, reduction in crop quality, water management problems, and less efficient utilization of labour (Patil et al., 2014; Gatachew et al., 2015; Prabhu et al., 2015; Singh et al., 2016). Primarily, weed reduced crop yield through 
competition for crop water, soil nutrient, light, and carbon dioxide. Weeds may also reduce crop yield by releasing allelopathic compounds into the environment (Marinov-Serafimov, 2015) and by providing a conducive environment for pest and virus (Fisichelli et al., 2014). Some parasitic weeds also cause considerable damage to cowpea, with substantial yield reduction especially in Africa (Emechebe et al., 1991; Lagoke et al., 1994).

The magnitude of yield depends on crop variety, weed density, type of weeds, weed persistence, duration of weed interference and crop management practices (Lagoke et al., 1982; Cousen, 1985; Kropff et al., 1992; Li et al., 2004; Milberg \& Hallgren, 2004; Osipitan \& Dille, 2017). For instance, among four cowpea cultivars examined by Nangju and Wanki (1980), the yield reductions due to weeds were $25 \%$ for VITA $1,33 \%$ for VITA 5, 46\% for ER-1 and 54\% for TVX33-IG. Li et al. (2004) reported $12.7 \%$ to $60 \%$ yield loss in cowpea due to weed while Tripathy and Singh (2001) reported yield loss as high as $82 \%$. A weed density study revealed that a density of 10 plants $\mathrm{m}^{-2}$ reduced cowpea yield by $25-53 \%$ while 80 plants $\mathrm{m}^{-2}$ reduced yield by 68 to $75 \%$ (International Institute for Tropical Agriculture (International Institute of Tropical Agriculture [IITA], 1977).

\subsection{Impact of Weed Interference Duration and Critical Time of Weed Removal in Cowpea}

The effects of weeds on crop yield depends on the duration of the interference and the life-history stage of the weed- crop system at which the interaction takes place (Knezevic et al., 2003). Weed interference is the detrimental effects of weed on crop resulting from their interactions with each other (Akobundu, 1987). Weeds associated with cowpea differ in flora and intensity from one region to another (Poku \& Akobundu, 1985). Cowpea is sensitive to weed competition like any other crop especially at the early stage of growth (Osipitan et al., 2016).

Impacts of duration of weed interference have been reported for grain legumes including cowpea. A season long weed interference could potentially reduce cowpea yield by 53 to $76 \%$ (Olorunmaiye \& Ogunfolaji, 2002; Adigun et al., 2014; Gupta et al., 2016). Allowing weed to interfere with cowpea growth for up to 50 days after crop emergence (DAE) reduced cowpea yield by 26 to 75\% (Olorunmaiye \& Ogunfolaji, 2002; Adigun et al., 2014). Delaying weed removal for up to 14 DAE was not encouraging as it could reduce cowpea yield by 4 to 15\% (Adigun et al., 2014).

The yield loss in crops due to weed interference may not be unconnected to inadequate fund and scarcity of labour among other factors during the crop growing season, particularly in developing countries. However, a concept, critical period of weed control (CPWC) has been developed to determine the most efficient period during the crop growing season to remove weed in order to prevent an "unacceptable yield loss" in crop. The CPWC often coincides with time of ground cover in cowpea. The magnitude of acceptable yield loss solely depends on the discretion of the farmers (Knezevic \& Datta, 2015). It provides farmers a decision tool necessary to manage their limited resources effectively on weed management. From a practical standpoint, an arbitrary level of 2 to $10 \%$ yield loss can be used to signify the critical time for weed removal. This range can allow a farmer to adjust timing of weed control depending on the risk one is willing to take (Knezevic et al., 2003). Critical period of weed control is recently being developed to manage herbicide resistant weeds in crops.

Weed competition is most critical during the first 14 to 40 days of cowpea growth (Medrano et al., 1973; Moody, 1973; Fadayomi, 1979; Tripathi \& Singh, 2001; Osipitan et al., 2016). Akobundu (1987) reported that frequency of weeding within $40 \mathrm{DAE}$ for most of grain legumes give crop yields comparable to keeping the crop weed free for the first $110 \mathrm{DAE}$. A period of weed removal, lasting up to approximately $30 \mathrm{DAE}$, was adequate to prevent yield loss of more than 2.5\% (Van Acker et al., 1993). Ngouajio et al. (1997) in a 3 year study found that the period to prevent more than 10\% yield loss was 3-4 weeks after sowing (approximately 14 to $21 \mathrm{DAE}$ ), and this level could be obtained by one weeding in beans. However, the critical period of weed control might vary with the environmental conditions, level of weed infestations, composition of weed population, pre-crop emergence management practices, soil moisture and fertility level, cowpea cultivar and plant density (Norsworthy \& Oliveira, 2004; Mohammadi et al., 2005; Adigun et al., 2014; Osipitan et al., 2016).

Cowpea sown in summer season is infested by a number of weed species that compete with the crop right from germination to harvest, affecting the crop yield adversely (Yadev et al., 1996). A study by Sweet and Minotti (1980) showed that moisture is implicated early in weed-crop competition before other growth factor become limiting. In the periods of moisture stress, crops that make more efficient use of water will be expected to yield more than the less efficient crops and the efficiency is affected by relative root volume occupied by each competing plants (Davies et al., 1967; Akobundu, 1987). Similarly, in a study conducted in a sub-humid climate with bi-modal rainfall, the impact of weed interference was reported to be more severe in late-season cowpea than in the early season crop because of limited available moisture (Ayeni \& Akobundu, 1984; Adigun et al., 
2014). Osipitan et al. (2016) reported that the duration of critical period of weed removal was longer in cowpea with lower plant density, suggesting the necessity for more time for weed removal. To provide precise information for growers, critical period of weed removal should be determined specifically for a particular region considering the weed composition, climatic conditions and agronomic practices.

\section{Weed Control in Cowpea}

Weed control encompasses reduction of the interference ability of an existing population of weeds in a crop, establishment of a barrier to further weeds infestation in the crop, and the prevention of weed problems in future crops either from the existing weed reservoir or from additions to that weed flora (Lacey, 1985). Weed management in cowpea has been with low-level of technology this is partly due to being mostly cultivated in less developed country. The nature of weed interference strongly determines the choice of weed management practices (Adigun, 2002). Different methods of weed control in cowpea have shown to minimize weed competition in cowpea (Osipitan et al., 2013; Getachew et al., 2015; Prabhu et al., 2015; Singh et al., 2016).

Weed control methods applicable to crops include preventive measures which involves all sanitary measures routinely used such as vigilance to note the presence of a strange plant on the field, rouging isolated weeds that have escaped control by other methods, inspection of cowpea seeds at entry points into country to ensure freedom from weed seeds (quarantine) and preventing weed spread to new cowpea fields. Other options are cultural, physical, biological and chemical weed control methods

\subsection{Cultural Weed Control}

Cultural method includes those farmers employ to give crop advantage over weeds through (but not limited to) crop rotation, planting density, cover cropping, favorable cowpea cultivar, soil fertility and water management. The use of early maturing cowpea variety would ensure quick ground cover for smothering weeds and less duration of weed control intervention. Crop rotation has been reported to help reduce weed population in crop in comparison to monoculture systems. The success of rotation systems for weed suppression appears to base on the use of crop sequences that create varying patterns of resource competition, allelopathic interference, soil disturbance, and mechanical damage to provide an unstable and frequently inhospitable environment that prevents the proliferation of a particular weed species (Liebman \& Dyck, 1993). Cowpea can be rotated with a variety of crops including but not limited to corn, pearl millet, sorghum, cassava and sunflower (Horst \& Hardter, 1992; Subbarao et al., 2000; Neves et al., 2015).

One of the widely researched cultural method that could potentially provide weed suppression and increase cowpea yield is planting density (or row spacing). Grain legumes planted with narrow spacing generally have quicker ground cover that provides shades for weed suppression. Variation in within intra-row-spacing has been shown to have less influence on grain yield of cowpea than differences in inter-row spacing (Adigun, 2002; Chattha et al., 2007). For example, Grantz (1979) evaluated semi-erect indeterminate CB5 cultivar of cowpea at row spacing of 10,20,30,40, and $61 \mathrm{~cm}$, with an inter-row spacing of $76 \mathrm{~cm}$. Large grain yields of 3000 to 3400 $\mathrm{kg} \mathrm{ha}^{-1}$ were obtained, but with no significant effects from within-row spacing with all treatments producing 250 pods $\mathrm{m}^{-2}$. Meanwhile an experiment conducted by Ismail and Hall (2001) on semi-dwarf and standard-height cowpea responses to inter-row spacing $(51,76$, and $102 \mathrm{~cm})$ showed that both the semi dwarf and standard height cowpea produced their greatest yield at the narrowest inter-row spacing $(51 \mathrm{~cm})$, though there were fewer seeds per pod at the narrowest inter-row spacing. Another report by Biswan et al. (2002) showed that population density had significant effect on pods per plant and seed yield in a grain legume. The highest pod per plant was recorded from the lowest population density. However, the highest number of pod per plant under lowest population density did not increase the seed yield. In contrast, the highest yield was found in intermediate population density with 33 plants per unit area. Sweet and Minotti (1980) reported that the most predictable and manageable form of competition (against weeds) is early shade and this is achievable through narrow spacing or increased plant density.

\subsection{Physical Weed Control}

Hand weeding is the most widely used physical weed control in cowpea. Reports had shown that two timely hand weeding within first 30 to 40 DAE are necessary to minimize weed competition in cowpea (Fadayomi, 1979; Chattha et al., 2007; Osipitan et al., 2013). Also, Fadayomi (1979) showed that hand weeding for three times within 42 days of crop growth gave yield similar to plots that are given weed-free control. Caution should be taken as hand weeding after ground cover and during reproductive stage could lead to yield reduction due to physical injury to cowpea (Adigun et al., 2014). However, physical method of weed control such as hand weeding is mostly expensive, labour intensive and strenuous. In addition to high cost, labour availability is uncertain thus making precision of weeding difficult to attain (Lagoke et al., 1981). The contribution of 
mechanical operations to weed control in cowpea production has not been widely investigated. In a preliminary study, Higuera et al. (2001) reported that tillage operation gave a satisfactory weed control in cowpea, however, there was higher associated crop injury in tillage compared to no-tillage treatments.

\subsection{Biological Weed Control}

Biological control technology has potential in cowpea production. It is the control or suppression of weeds by natural or introduced enemies, or by the manipulation of weeds, organism, or environment (Anon, 1983). The objective of biological weed control is not the eradication of weeds but the reduction and long term stabilization of weed density to a sub-economical level. Preliminary investigations were made in New Guinea into the possibilities of biological control of wild poinsettia, a serious weed problem in cowpea, but result has not so far been published. Meanwhile classic biological weed control involving the use of insects has been used successfully to control prickly pear (Opunita spp.), St. Johnswort (Hypericum perforatum L.) and more recently alligator weed (Alternanthera philoxeroides (mart) Griseb) (Andres, 1981; Tingle et al., 2016; DiTomaso et al., 2017). Reports had shown that legumes including cowpea are used as live mulch for weed suppression in other crops (Tarawali et al., 1997). Biological weed control has little relevance in broad-spectrum weed control in cowpea because no insect is known to feed on a cross-section of cowpea weeds without attacking the crop. Bio-herbicides, a relatively recent innovation in biological weed control, are now in the market (Cordeau et al., 2016).

\subsection{Chemical Weed Control}

An important and relatively less expensive control option is chemical weed control, which involves the use of different herbicides applied as PRE and POST-emergence of crops. Gianessi and Reigner (2007) estimated that non-use of herbicides for weed control in crops could increase cost of production by $20 \%$. The use of herbicide for weed control in cowpea can significantly reduce the need of labour for hand weeding thereby lowering the cost of production. On per hectare estimation, herbicide could replace approximately the need for 10 laborers in weed control (Gianessi \& Reigner, 2007). Examples of herbicides used in weed control in cowpea include, PRE: pendimenthalin $\left(1.5 \mathrm{~kg}\right.$ a.i. ha $\left.{ }^{-1}\right)$, fluchloralin $\left(1.0\right.$ or $1.5 \mathrm{~kg}$ a.i. ha $\left.{ }^{-1}\right)$, phenoxaprop-p-ethyl $\left(0.08 \mathrm{~kg}\right.$ a.i. ha $\left.{ }^{-1}\right)$, metolachlor and prometryn mixture $\left(1.5 \mathrm{~kg}\right.$ a.i. $\left.\mathrm{ha}^{-1}\right)$, Oxyfluorfen $\left(0.2 \mathrm{~kg}\right.$ a.i ha $\left.{ }^{-1}\right)$; POST: quizalofop ethyl $(0.05$ $\mathrm{kg}$ a.i. $\left.\mathrm{ha}^{-1}\right)$, imazethapyr $\left(0.075 \mathrm{~kg}\right.$ a.i. $\left.\mathrm{ha}^{-1}\right)$ and fluazifop-butyl $\left(0.19 \mathrm{~kg}\right.$ a.i. ha $\left.{ }^{-1}\right)$. Rottboellia cochinchinensis (Itch grass) was effectively controlled with pendimenthalin (Akobundu, 1982) and fluazifob-butyl (IITA, 1989) applied pre-emergence and post-emergence respectively. Metolachlor and most herbicides used for broad leaf weed control in cowpea have consistently failed to give control of Euphorbia heterophylla (milkweed) but imazethapyr, an experimental herbicides for milkweed control in cowpea has provided good control of this weed (Poku \& Akobundu, 1985). Also, a tank-mix of metribuzin and metolachlor was found to suppress milkweed long enough to minimize yield reduction (IITA, 1977). In southern guinea zone of Nigeria where Vernonia galamensis (ironweed) poses a problem, a tank mix of chloramben and metolachor provided satisfactory control (Poku \& Akobundu, 1985).

Generally, cowpea is more sensitive to herbicide than most of the other grain legumes crops (Akobundu, 1987). For example, bentazon has been effectively used for post emergence control of many annual broadleaf weeds in temperate agriculture (Barrentine \& Mc Whorter, 1972; Anderson, 1983) but was phytotoxic to cowpea and failed to control commonly occurring weeds of cowpea. Similarly, alachlor was found to be phytotoxic to cowpea in the forest transition zone in Nigeria (Moody, 1973; Akobundu, 1982) but found safe on the crop at higher rate in the southern guinea savanna zone in Nigeria and India (Sigh et al., 1975; Lagoke et al., 1982). These results may reflect varietals response of cowpea to herbicides.

According to Silva et al. (2003), a best post emergence weed control in cowpea was provided by phenoxaprop-p-ethyl at the rate of $0.080 \mathrm{~kg}$ a.i. ha ${ }^{-1}$ and it was mostly effective against grasses. However, these herbicide treatments alone have been reported inadequate in their ability to provide acceptable season long and wide-spectrum weed control without a supplementary weed control (Adigun et al., 1993; Osipitan et al., 2013).

\subsection{Integrated Weed Control in Cowpea}

Integrated weed management combines weed control practices that are effective, sustainable and perhaps, economical (Lamichhane et al., 2017). No one weed control method is applicable in all cases because of the wide variability in soil type, climate conditions, growth habits and nature of weed, therefore, a combination of two or more weed control methods is likely to prove more effective than any single method in alleviating the build-up of hard to kill weeds (including herbicide resistant ones). 
The conventional method of weeding such as hand weeding is expensive, and labour is not usually available during the growing season due to workload (Khan et al., 2000). The use of herbicides in cowpea to control weeds appears to be useful (Dadari, 2003; Silva, 2003), but herbicides are mostly effective only against selected weed species, which results in unsatisfactory broad spectrum weed control in cowpea (Osipitan et al., 2013). So there is need to develop an integrated weed management approach, which should be efficient, cost effective and environmentally safe (Chattha et al., 2007).

Parasuraman (2000) found that application of pendimenthalin (1.5 or $\left.2.0 \mathrm{~L} \mathrm{ha}^{-1}\right)$ or fluchloralin $\left(1.0\right.$ or $\left.1.5 \mathrm{~L} \mathrm{ha}^{-1}\right)$ as PRE plus hand-weeding at 30 DAE resulted in significant reduction in weed population and weed dry matter and increased in crop yield in rain-fed cowpea. Patel et al. (2003) conducted a field experiment to evaluate weed management strategy for cowpea. Pre-emergence application of pendimenthalin at $0.75 \mathrm{~kg}$ a.i. $\mathrm{ha}^{-1}+$ weeding at 5 weeks after sowing gave a higher grain yield compared to other treatments. Jaibir et al. (2004) reported that pendimenthalin at $1.0 \mathrm{~kg}$ a.i. ha ${ }^{-1}+$ hand weeding at about $21 \mathrm{DAE}$ gave the highest cowpea yield and weed density and dry biomass was lowest in this treatment. Chattha et al. (2007) conducted a field experiment to evaluate yield of cowpea as affected by weed control methods under rain-fed conditions. Maximum reduction in density and biomass of weeds were observed by chemical weeding at 2-3 leaf stage of weeds + hand weeding at 42 DAE. Similar treatment out yielded other treatments in terms of number of pods per plant, number of seeds per pod, 1000 grain weight, biomass and grain yield. Integration of row spacing, physical, and chemical weed control methods has also shown a great potential in weed management with subsequent increase in cowpea yield (Osipitan et al., 2013; Adigun et al. 2014).

\section{Conclusion}

In spite of the great economic potential of cowpea as both domestic and commercial crop, its production in West and many parts of Africa is limited by a number of constraints, which include insect pests, diseases and weeds. Yield losses cause by weeds alone in cowpea production can be as high as $76 \%$ depending on the cowpea cultivar, environment and weed management practices. A timely weed removal at the critical period, which falls within 40 days after cowpea emergence, would help to prevent unacceptable yield. Handweeding is the most widely used weed control method in cowpea. Cultural practices such as narrow row spacing and planting of early maturing varieties are also used for weed control in cowpea. There are limited number of selective herbicides with wide spectrum for weed control in cowpea. However, an integrated practices that involved pre-emergence weed control using herbicides or physical weeding, and a complimentary weed removal that would ensure weed removal up to 40 days after cowpea emergence could substantially prevent yield losses associated weed interference.

\section{References}

Abudulai, M., Kusi, F., Seini, S. S., Seidu, A., Nboyine, J. A., \& Larbi, A. (2017). Effects of planting date, cultivar and insecticide spray application for the management of insect pests of cowpea in northern Ghana. Crop Protection, 100, 168-176. https://doi.org/10.1016/j.cropro.2017.07.005

Adigun J. A., \& Lagoke, S. T. O. (1994). Chemical weed control in maize/groundnut mixture in the northern Guinea savanna ecological zone of Nigeria. Nigerian Agricultural Journal, 27, 104-113.

Adigun, J. A. (2002). Chemical weed control in transplanted rain fed tomato (Lycoperiscon esculentus Mill) in the forest-Savanna transition zone of south western Nigeria. ASSET, 2(2), 141-150.

Adigun, J. A., Lagoke, S. T. O., Kumar, V., \& Erinle, I. D. (1993). Weed management studies in transplanted tomato in the Nigerian Savanna. Samaru Journal of Agricultural Research, 10, 29-39.

Adigun, J., Osipitan, A. O., Lagoke, S. T., Adeyemi, R. O., \& Afolami, S. O. (2014). Growth and yield performance of cowpea (Vigna unguiculata (L.) Walp) as influenced by row-spacing and period of weed interference in South-West Nigeria. Journal of Agricultural Science, 6(4), 188. https://doi.org/10.5539/ jas.v6n4p188

Adusei, G., Gaiser, T., Boukar, O., \& Fatokun, C. (2016). Growth and yield responses of cowpea genotypes to soluble and rock P fertilizers on acid, highly weathered soil from humid tropical West Africa. International Journal of Biological and Chemical Sciences, 10(4), 1493-1507. https://doi.org/10.4314/ijbcs.v10i4.3

Ajeigbe, H. A., Singh, B. B., \& Oseni, T. O. (2005). Cowpea-Cereal intercrop productivity in the Sudan Savannah Zone of Nigeria as affected by planting pattern, crop variety and pest management. African Crop Science Journal, 13(4), 269-279. 
Akobundu, I. O. (1982). The role of Conservation Tillage in Weed Management in the Advancing Countries. FAO Plant Production and Protection Paper, 44 (pp. 23-39).

Akobundu, I. O. (1987). Weed Science in the Tropics: principles and practices (p. 533). John Wiley and Sons Ltd., Great Britain.

Anderson, W. P. (1983). Weed Science: Principles (2nd ed.). West publishing company, St. Louise.

Andres, L. A. (1981). Biological Control of Naturalized and Native Plants. In G. C. Papavizas (Ed.), Biological Control in Crop Production (pp. 341-349). Toowa, NJ, Allaheld Osmum and Co.

Anon, T. E. (1983). Plant Protection: Fundamental Aspects. Proceedings of symposia, IX International Congress of Plant Protection (Vol. 1). Washington, DC, USA.

Ashton, M. (1991). Weed science principles and practice (3rd ed.). West Publishing Company.

Asiwe, J. A. N., \& Kutu, R. F. (2007). Effect of plant spacing on yield, weeds, insect infestation and leaf blight of bambara groundnut. Proceedings of African Crop Science Society, 4, 1947-1950.

Ayeni, A. O., \& Akonbubdu, I. O. (1984). Weed Interference in Maize, Cowpea and Maize- Cowpea Intercrop in a Subhumid Tropical Environment. Weed Research, 24, 281-290. https://doi.org/10.1111/j.1365-3180. 1984.tb00607.x

Barrentine, W. L., \& McWhorter, C. G. (1972). Cocklebur control with BAY-94337 and bentazon in soybeans. Proc. South. Weed Sci. Soc (Vol. 25, p. 104).

Biswan, D. K., Haque, M. M., Hamid, A., Ahmed, J. U., \& Rahman, M. A. (2002). Influence of plant population density on growth and yield of two blackgram varieties. Pakistan Journal of Agronomy, (2-3), 83-85.

Chandler, J. M., \& Meredity Jr., W. R. (1984). Yield of Three Cotton (Gossypium hirsutum) cultivars as influenced by spurred anoda (Anoda cristata) competition. Weed Science, 31, 303-37.

Chattha, M. R., Jumai, M., \& Mahmood, T. Z. (2007). Yield and yield component of cowpea as affected by weed control method under rain-fed conditions of Pakistan. Int. J. Agri. Biol., 9(1), 76-79.

Cordeau, S., Triolet, M., Wayman, S., Steinberg, C., \& Guillemin, J. P. (2016). Bioherbicides: Dead in the water? A review of the existing products for integrated weed management. Crop Protection, 87, 44-49. https://doi.org/10.1016/j.cropro.2016.04.016

Cousens, R. (1985). A simple model relating yield loss to weed density. Annals of Applied Biology, 107(2), 239-252. https://doi.org/10.1111/j.1744-7348.1985.tb01567.x

Dadari, S. A. (2003). Evaluation of herbicides in cotton/cowpea mixture in the Northern Guinea Savannah. $J$. Sustainable Agric. Environ, 5, 153-9.

Davies, F. G., Johnson, W. C., \& Wood, F. (1967). Weed Root Profile. Agron. J., 59, 555-556. https://doi.org/ 10.2134/agronj1967.00021962005900060020x

DiTomaso, J. M., Van Steenwyk, R. A., Nowierski, R. M., Vollmer, J. L., Lane, E., Chilton, E., ... Dionigi, C. P. (2017). Enhancing the effectiveness of biological control programs of invasive species through a more comprehensive pest management approach. Pest Management Science, 73(1), 9-13. https://doi.org/ $10.1002 /$ ps.4347

Emechebe, A. M., Sigh, B. B., \& Laleji, I. D. K. (1991). Cowpea Striga problem and Research in Nigeria (pp. 18-28). Cambating Striga in Africa, IITA, Ibadan, Nigeria.

Evans, S. P., Knezevic, S. Z., Shapiro, C., \& Lindquist, J. L. (2003). Nitrogen level affects critical period for weed control in corn. Weed Sci. https://doi.org/10.1614/0043-1745(2003)051[0408:NAITCP]2.0.CO;2

Fadayomi, O. C. (1979). Effects of Crop Spacing on Weed Competition and Seed Yield in Cowpea (Vigna unguilata (L.) Walp cv Ife Brown). Ife Journal of Agriculture, 1, 45-50.

FAO. (2014). Statistical Data Base. Food and Agricultural Organization of the United Nations. Retrieved from http://www.fao.org

Fisichelli, N. A., Abella, S. R., Peters, M., \& Krist, F. J. (2014). Climate, trees, pests, and weeds: Change, uncertainty, and biotic stressors in eastern US national park forests. Forest Ecology and Management, 327, 31-39. https://doi.org/10.1016/j.foreco.2014.04.033

Fletcher, W. W. (1983). Recent Advances in Weed Research (pp. 1-2). Common Wealth Agricultural Bureaux. 
Getachew, M., Sharma, J. J., Lisanework, N., \& Tamado, T. (2015). Effect of integrated weed management practices on weeds infestation, yield components and yield of cowpea [Vigna unguiculata (L.) Walp.] in eastern Wollo, northern Ethiopia. American Journal of Experimental Agriculture, 7(5), 326-346. https://doi.org/10.9734/AJEA/2015/14513

Gianessi, L. P., \& Reigner, N. P. (2007). The value of herbicides in US crop production. Weed Technology, 21(2), 559-566. https://doi.org/10.1614/WT-06-130.1

Grantz, D. A. (1979). Earliness and drought adaptation of cowpea (Vigna unguiculata (L.) Walp) (M. Sc. Thesis, University of California. Univ. of Calif, Div. Agric. Nat. Res. Publ. 21518).

Gupta, K. C., Gupta, A. K., \& Rani, S. (2016). Weed management in cowpea [Vigna unguiculata (L.) Wasp.] under rainfed conditions. International Journal of Agricultural Sciences, 12(2), 238-240. https://doi.org/ 10.15740/HAS/IJAS/12.2/238-240

Higuera, A., Gallaher, R. N., \& MacDonald, G. E. (2001). Response of cowpea (Vigna unguiculata) to tillage and herbicide management (p. 65). Southern Conservation Tillage Conference.

Horst, W. J., \& Härdter, R. (1994). Rotation of maize with cowpea improves yield and nutrient use of maize compared to maize monocropping in an alfisol in the northern Guinea Savanna of Ghana. Plant and Soil, 160(2), 171-183. https://doi.org/10.1007/BF00010143

IITA. (1977). Grain Legume Improvement Program Annual Report (p. 78). Ibadan, Nigeria, IITA.

IITA. (1989). Research Highlights (p. 81). Ibadan, Nigeria, IITA.

Ismail, A. M., \& Hall, A. E. (2001). Semi-dwarf and standard-height cowpea responses to row spacing in different environments. Crop Science, 40(6), 1618-1623. https://doi.org/10.2135/ cropsci2000.4061618x

Kanteh, S. M., Norman, J. E., \& Sherman-Kamara, J. (2014). Effect of Plant Density and Weeding Regime on Population and Severity of Aphids (Aphis craccivora Koch) and Foliage Beetles (Ootheca mutabilis Sahl) on Cowpea in Sierra Leone. Neuropharmacology, 22(3), 309-15. https://doi.org/10.5923/j.ijaf.20140401.04

Khan, B. M., Asif, M., Hussain, N., \& Iqbal, M. (2000). Agroecconomic impact of different weed control strategies in wheat. J. Res. Sci., 11, 46-9.

Knezevic, S. Z., \& Datta, A. (2015). The critical period for weed control: revisiting data analysis. Weed Science, 63(SP1), 188-202. https://doi.org/10.1614/WS-D-14-00035.1

Knezevic, S. Z., Evans, S. P., \& Mainz, M. (2003). Row spacing influences the critical timing for weed removal in soybean (Glycine max). Weed Technol., 17, 666-673. https://doi.org/10.1614/WT02-49

Knezevic, S. Z., Evans, S. P., Blankenship, E. E., Van Acker, R. C., \& Lindquist, J. L. (2002). Critical period for weed control: The concept and data analysis. Weed Sci., 50, 773-786. https://doi.org/10.1614/0043-1745 (2002)050[0773:CPFWCT]2.0.CO;2

Kormawa, P. M., Chianu, J. N., \& Manyong, V. M. (2000). Cowpea demand and supply patterns in West Africa: The case of Nigeria. Proceedings of World Cowpea Conference III, September 4-7, 2000 (pp. 376-386). IITA, Ibadan, Nigeria.

Kropff, M. J., Weaver, S. E., \& Smits, M. A. (1992). Use of ecophysiological models for crop- weed interference: Relations amongst weed density, relative time of weed emergence, relative leaf area, and yield loss. Weed Sci., 40(2), 296-301. http://doi.org/10.1017/S0043174500057374

Lagoke, S. T. O., Chaudhary, A. H., \& Chandra-Singh, D. J. (1982). Chemical Weed Control in Rainfed Cowpea in the Guinea Savanna Zone of Nigeria. Weed Research, 22(1), 17-22. http://doi.org/10.1111/j.1365-3180. 1982.tb00138.x

Lagoke, S. T. O., Choudhary, A. H., \& Tanko, Y. M. (1981). Weed control in rain fed groundnuts (Arachis hypogeal L.) in the guinea savanna ecological zone of Nigeria. Weed Research, 21, 119-125. http://doi.org/ 10.1111/j.1365-3180.1981.tb00105.x

Lagoke, S. T. O., Shebayan, J. Y., Weber, G., Olufajo, O., Elemo, K., Adu, J. K., ... Adeoti, A. A. (1994). Survey of Striga Problems and Evaluation of Strga Control Methods and Packages in Crop in the Nigeria Savanna. In S. T. O. Lagoke, R. Hoevers, S. S. Mboob \& R. Traboulsi (Eds.), Improving Striga management in Africa (pp. 91-120). Proceedings, $2^{\text {nd }}$ General Workshop on Pan-African Striga Control Network (PASCON) Jun 23-29, 1991, Nairobi, Kenya, FAO/PASCON. Accra, Ghana. 
Lamichhane, J. R., Devos, Y., Beckie, H. J., Owen, M. D., Tillie, P., Messéan, A., \& Kudsk, P. (2017). Integrated weed management systems with herbicide-tolerant crops in the European Union: Lessons learnt from home and abroad. Critical Reviews in Biotechnology, 37(4), 459-475. https://doi.org/10.1080/07388551.2016. 1180588

Langyintuo, A. S., Lowenberg-DeBoer, J., Faye, M., Lambert, D., Ibro, G., Moussa, B., \& Ntoukam, G. (2003). Cowpea supply and demand in West and Central Africa. Field Crops Research, 82(2), 215-231. https://doi.org/10.1016/S0378-4290(03)00039-X

Li, R., Guidong, Z., Yumei Z., \& Zhanzhi, X. (2004). Damage loss and control technology of weeds in cowpea field. Weed Sci., 2, 25-6.

Liebman, M., \& Dyck, E. (1993). Crop rotation and intercropping strategies for weed management. Ecological Applications, 3(1), 92-122. https://doi.org/10.2307/1941795

Little, T. M., \& Hills, E. J. (1978). Agricultural Experimentation: Design and Analysis (p. 350). John Willey, New York.

Marechal, R. (1985). Cowpea Taxonomy Origin and Germplasm. In S. R. Singh \& K. O. Rachie (Eds.), Cowpea research, production and utilization (pp. 11-21). John Willey and Sons, Chicheser, UK.

Marinov-Serafimov, P. (2015). Determination of allelopathic effect of some invasive weed species on germination and initial development of grain legume crops. Pesticidi I Fitomedicina, 25(3), 251-259. https://doi.org/10.2298/PIF1003251M

Medrano, S. C., Arila, L. R., \& Villasmil, P. J. J. (1973). Determination of the Critical Period Weed Competition in Cowpea. Revista de la faculad de Agronomy Universidad de zu lia, 2, 7-13.

Mekonnen, G., Sharma, J. J., Negatu, L., \& Tana, T. (2017). Effect of Planting Pattern and Weeding Frequency on Weed Infestation, Yield Components and Yield of Cowpea [Vigna unguiculata (L.) Walp] in Wollo, Northern Ethiopia. Agriculture, Forestry and Fisheries, 6(4), 111. https://doi.org/10.11648/j.aff.2017 0604.12

Milberg, P., \& Hallgren, E. (2004). Yield loss due to weeds in cereals and its large-scale variability in Sweden. Field Crops Research, 86(2), 199-209. https://doi.org/10.1016/j.fcr.2003.08.006

Mohamed, E. S., Nourai, A. H., Mohamed, G. E., Mohamed, M. I., \& Saxena, M. C. (1997). Weeds and weed management in irrigated lentil in Northern Sudan. Weed Res., 37, 211-218. https://doi.org/10.1046/ j.1365-3180.1997.d01-35.x

Mohammadi, G., Javanshir, A., Khooie, F. R., Mohammadi, S. A., \& Zehtab Salmasi, S. (2005). Critical period of weed interference in chickpea. Weed Res., 45, 57-63. https://doi.org/10.1111/j.1365-3180.2004.00431.x

Moody, K. (1973). Weed Control in Cowpea. Proc. $3^{\text {rd }}$ Weed Sci. Soc. Nig. (pp. 14-22).

Nangju, D., \& Wanki, T. (1980). Effects of Density, Plant Type and Season on growth and Yield of Cowpea, Journal of the American Society of Horticultural Science, 104(4), 446-470.

Neves, A. L. R., Lacerda, C. F. D., Sousa, C. H. C. D., Silva, F. L. B. D., Gheyi, H. R., \& Ferreira, F. J. (2015). Growth and yield of cowpea/sunflower crop rotation under different irrigation management strategies with saline water. Ciência Rural, 45(5), 814-820. https://doi.org/10.1590/0103-8478cr20131657

Ngouajio, M., Foko, J., \& Fouejio, D. (1997). The critical period of weed control in common bean (Phaseolus vulgaris L.) in Cameroon. Crop Prot., 16, 127-233. https://doi.org/10.1016/S0261-2194(96)00085-3

Norsworthy, J. K., \& Oliveira, M. J. (2004). Comparison of the critical period for weed control in wide and narrow row corn. Weed Science, 52, 802-807. https://doi.org/10.1614/WS-03-165R

Nutman, A. A. (1971). Nitrogen fixation by cowpea (Vigna unguilata (L.) Walp). Soil Sci., 4, 25-6.

Olorunmaiye, K. S., \& Ogunfolabi, R. J. (2002). Effect of density and duration of Euphobia heterophylla (L.) on performance of cowpea. NISEB Journal, 2(1), 017-022.

Osipitan, O. A., \& Dille, J. A. (2017). Fitness Outcomes Related to Glyphosate Resistance in Kochia (Kochia scoparia): What Life History Stage to Examine? Frontiers in Plant Science, 8, 1090. https://doi.org/ 10.3389/fpls.2017.01090

Osipitan, O. A., Adigun, J. A., \& Kolawole, R. O. (2016). Row spacing determines critical period of weed control in crop: Cowpea (Vigna unguiculata) as a case study. Azarian Journal of Agriculture, 3(5), 90-96. 
Osipitan, O. A., Adigun, J. A., Lagoke, S. T. O., \& Afolami, S. O. (2013). Effect of inter-row spacing and weed control methods on growth and yield of cowpea (Vigna unguiculata L. Walp) in South Western Nigeria. Nigeria Journal of Plant Protection, 27, 97-111.

Parasuraman, P. (2000). Weed Management in rain-fed cowpea (Vigna unguiculata) and green gram (Phaseolus radiatus) under North-Western Agro-climate zone of Tamil Nadu. Indian J. Agron, 45, 732-6.

Patel, M. M., Patel, A. L., Patel, I. C., Tikka, S. B. S., Henry, A., Kumar, D., \& Singh, N. B. (2003). Weed control in cowpea under rain fed conditions. Proceeding of National Symposium on Arid Legumes, for Food Nutrition Security and Promotion of Trade (pp. 203-6). Hisar, India, May 15-16, 2002. Advances in Legumes Research.

Patil, B. C., Padanad, L. A., Yashvantkumar, K. H., Soumya, S., \& Ravi, L. (2014). Efficacy and economics of integrated weed management in vegetable cowpea [Vigna unguiculata (L.) Walp]. Agriculture Update, 9(1), 124-127.

Poku, J. A., \& Akobundu, I. O. (1985). Weed Management for Small Holdings. In S. R. K. O. Singh \& Rachie (Eds.), Cowpea Research, Production and Utilization (Vol. 25, pp. 327-334). Willey and Sons, Chicheser, UK.

Prabhu, G., Srinivasan, R., Kantwa, S. R., Palsaniya, D. R., \& Chaudhary, M. (2015). Weed seed bank studies in the field of Fodder Cowpea [Vigna unguiculata (L.)]. International Journal of Applied and Pure Science and Agriculture, 1, 83-87.

Silva, J. B. F., Pitombeira, J. B., Nunes, R. P., \& Pinho, J. L. (2003). Weed control in cowpea under no till system. Planta Daninha, 21, 151-7. https://doi.org/10.1590/S0100-83582003000100019

Singh, M. C., \& Sairam, C. V. (2016). Effect of spacing and intercropping with cowpea on weed growth in banana. International Journal of Science, Environment and Technology, 5(2), 558-563.

Subbarao, G. V., Renard, C., Payne, W. A., \& Bationo, A. (2000). Long-term effects of tillage, phosphorus fertilization and crop rotation on pearl millet-cowpea productivity in the West-African Sahel. Experimental Agriculture, 36(2), 243-264. https://doi.org/10.1017/S0014479700002106

Sweet, R. D., \& Minotti, P. L. (1980). Studies in Weed-Crop Competition. In I. O. Akobundu (Ed.), Weeds and their control in the humid and subhumid tropics. IITA Proceeding Series No. 3 (pp. 252-63). Ibadan, Nigeria.

Tarawali, S. A., Singh, B. B., Peters, M., \& Blade, S. F. (1997). Cowpea Haulms as Fodder. In B. B. Singh, D. R. Mohan Raj, K. E. Dashiell, \& L. E. N. Jackai (Eds.), Advances in Cowpea Research (p. 326).

Thio, I. G., Zida, E. P., Sawadogo, M., \& Sérémé, P. (2016). Current status of Colletotrichum capsici strains, causal agents of Brown blotch disease of cowpea in Burkina Faso. African Journal of Biotechnology, 15(5), 96-104. https://doi.org/10.5897/AJB2015.14988

Tingle, J. L., Cook-Patton, S. C., \& Agrawal, A. A. (2016). Spillover of a biological control agent (Chrysolina quadrigemina) onto native St. Johnswort (Hypericum punctatum). Peer J, 4, e1886. https://doi.org/10.7717/ peerj. 1886

Tripathi, S. S., \& Singh, G. (2001). Critical period of weed competition in summer cowpea (Vigna unguiculata L.). Indian J. Weed Sci., 33, 67-8.

Ugbe, L. A., Ndaeyo, N. U., \& Enyong, J. F. (2016). Efficacy of Selected Herbicides on Weed Control, Cowpea (Vigna Unguiculata L. Walp) Performance and Economic Returns in Akamkpa, Southeastern Nigeria. International Journal, 19, 19-27.

Vaillancourt, R. E., \& Weeden, N. F. (1992). Chloroplast DNA polymorphism suggests Nigerian center of domestication for the cowpea, Vigna unguiculata (Leguminosae). American Journal of Botany, 79(10), 1194-1199. https://doi.org/10.2307/2445219

Van Acker, R. C., Swanton, C. J., \& Weise, S. (1993). The critical period of weed control in soybean (Glycine $\max ($ L.) Merr.).Weed Sci., 41, 194-200. https://doi.org/10.1017/S0043174500076050

Yadev, B. D., Joon, R. K., \& Singh, J. V. (1996). Contribution of production sectors on growth and seed yield of cowpea under rain fed conditions. Forage Res., 24, 157-8. 


\section{Copyrights}

Copyright for this article is retained by the author(s), with first publication rights granted to the journal.

This is an open-access article distributed under the terms and conditions of the Creative Commons Attribution license (http://creativecommons.org/licenses/by/4.0/). 